\title{
Front Matter: Volume 8957
}

, "Front Matter: Volume 8957," Proc. SPIE 8957, Plasmonics in Biology and Medicine XI, 895701 (12 March 2014); doi: 10.1117/12.2062790

SPIE. Event: SPIE BiOS, 2014, San Francisco, California, United States 


\section{PROGRESS IN BIOMEDICAL OPTICS AND IMAGING}

\section{Plasmonics in Biology and Medicine XI}

Tuan Vo-Dinh

Joseph R. Lakowicz

Editors

1-2 February 2014

San Francisco, California, United States

Sponsored and Published by

SPIE 
The papers included in this volume were part of the technical conference cited on the cover and title page. Papers were selected and subject to review by the editors and conference program committee. Some conference presentations may not be available for publication. The papers published in these proceedings reflect the work and thoughts of the authors and are published herein as submitted. The publisher is not responsible for the validity of the information or for any outcomes resulting from reliance thereon.

Please use the following format to cite material from this book:

Author(s), "Title of Paper," in Plasmonics in Biology and Medicine XI, edited by Tuan Vo-Dinh, Joseph R. Lakowicz, Proceedings of SPIE Vol. 8957 (SPIE, Bellingham, WA, 2014) Article CID Number.

ISSN: 1605-7422

ISBN: 9780819498700

Published by

SPIE

P.O. Box 10, Bellingham, Washington 98227-0010 USA

Telephone +1 3606763290 (Pacific Time) · Fax +1 3606471445

SPIE.org

Copyright $@ 2014$, Society of Photo-Optical Instrumentation Engineers.

Copying of material in this book for internal or personal use, or for the internal or personal use of specific clients, beyond the fair use provisions granted by the U.S. Copyright Law is authorized by SPIE subject to payment of copying fees. The Transactional Reporting Service base fee for this volume is $\$ 18.00$ per article (or portion thereof), which should be paid directly to the Copyright Clearance Center (CCC), 222 Rosewood Drive, Danvers, MA 01923. Payment may also be made electronically through $\mathrm{CCC}$ Online at copyright.com. Other copying for republication, resale, advertising or promotion, or any form of systematic or multiple reproduction of any material in this book is prohibited except with permission in writing from the publisher. The CCC fee code is $1605-7422 / 14 / \$ 18.00$.

Printed in the United States of America.

Publication of record for individual papers is online in the SPIE Digital Library.

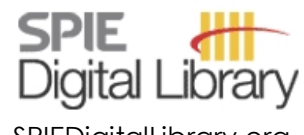

SPIEDigitalLibrary.org

Paper Numbering: Proceedings of SPIE follow an e-First publication model, with papers published first online and then in print and on CD-ROM. Papers are published as they are submitted and meet publication criteria. A unique, consistent, permanent citation identifier (CID) number is assigned to each article at the time of the first publication. Utilization of CIDs allows articles to be fully citable as soon as they are published online, and connects the same identifier to all online, print, and electronic versions of the publication. SPIE uses a six-digit CID article numbering system in which:

- The first four digits correspond to the SPIE volume number.

- The last two digits indicate publication order within the volume using a Base 36 numbering

system employing both numerals and letters. These two-number sets start with 00, 01, 02, 03, 04,

$05,06,07,08,09,0 A, 0 B \ldots$. OZ, followed by 10-1Z, 20-2Z, etc.

The CID Number appears on each page of the manuscript. The complete citation is used on the first page, and an abbreviated version on subsequent pages. Numbers in the index correspond to the last two digits of the six-digit CID Number. 


\section{Contents}

vii Conference Committee

PLASMONICS AND SERS I

895702 Low-cost, high-sensitivity SERS nano-bio-chip for kinase profiling, drug monitoring and environmental detection: a translational plafform technology [8957-1]

Y. Chen, L. Liu, Univ. of Illinois at Urbana-Champaign (United States)

895703 Plasmonic gold nanostar for biomedical sensing [8957-2]

Y. Liu, H. Yuan, A. M. Fales, T. Vo-Dinh, Duke Univ. (United States) and Fitzpatrick Institute for

Photonics, Duke Univ. (United States)

\section{PLASMONICS AND SERS II}

895707 Bifunctional nanoparticles for surface-enhanced Raman spectroscopy-based leukemia biomarker detection [8957-6]

D. Mehn, C. Morasso, R. Vanna, D. Schiumarini, M. Bedoni, Fondazione Don Carlo Gnocchi (Italy); F. Ciceri, IRCCS Ospedale San Raffaele (Italy); F. Gramatica, Fondazione Don Carlo Gnocchi (Italy)

895708 Application of SERS spectroscopy for detection of trace components in urinary deposits [8957-7]

M. Pucetaite, M. Velicka, S. Tamosaityte, V. Sablinskas, Vilnius Univ. (Lithuania)

895709 Biomolecular sensing for cancer diagnostics using highly reproducible SERS substrates [8957-8]

A. C. De Luca, Institute of Protein Biochemsitry, CNR (Italy); P. Reader-Harris, M. Mazilu, Univ. of St. Andrews (United Kingdom); S. Managò, S. Mariggiò, D. Corda, Institute of Protein Biochemsitry, CNR (Italy); A. Di Falco, Univ. of St. Andrews (United Kingdom)

\section{PLASMONIC BIOSENSING I}

8957 OA Plasmonic spectra of individual subwavelength particles under the infrared microscope: cells and airborne dust [8957-9]

J. V. Coe, D. B. Lioi, L. Shaffer, M. A. Malone, A. Luthra, A. Ravi, The Ohio State Univ. (United States) 
8957 OE Plasmonic improvement of microcavity biomedical sensor spectroscopic characteristics [8957-14]

V. A. Saetchnikov, E. A. Tcherniavskaia, A. V. Saetchnikov, Belarusian State Univ. (Belarus);

G. Schweiger, A. Ostendorf, R. Ghadiri, Ruhr-Univ. Bochum (Germany)

8957 0I Three dimensional metallic nanostructures for bulk and bio-SPR sensing applications [8957-18]

M. Najiminaini, Lawson Health Research Institute (Canada), Simon Fraser Univ. (Canada), and Schulich School of Medicine and Dentistry, The Univ. of Western Ontario (Canada); E. Ertorer, The Univ. of Western Ontario (Canada); H. Jiang, B. Kaminska, Simon Fraser Univ. (Canada); S. Mittler, The Univ. of Western Ontario (Canada); J. J. L. Carson, Lawson Health Research Institute (Canada) and Schulich School of Medicine and Dentistry, The Univ. of Western Ontario (Canada)

8957 OK DNA-Aptamer optical biosensors based on a LPG-SPR optical fiber platform for point-ofcare diagnostic [8957-20]

L. Coelho, INESC Porto (Portugal) and Univ. do Porto (Portugal); R. B. Queirós, INESC Porto (Portugal); J. L. Santos, INESC Porto (Portugal) and Univ. do Porto (Portugal);

M. C. L. Martins, Instituto de Engenharia Biomédica (Portugal); D. Viegas, P. A. S. Jorge, INESC Porto (Portugal)

\section{PLASMONICS AND FLUORESCENCE}

8957 OM Metal-enhanced fluorescence of chlorophylls in light-harvesting complexes coupled to silver nanowires [8957-22]

M. Twardowska, D. Kowalska, M. Olejnik, S. Maćkowski, Nicolaus Copernicus Univ. (Poland)

8957 ON Plasmonic hybrid nanostructure with controlled interaction strength [8957-23]

J. K. Grzelak, B. Krajnik, Nicolaus Copernicus Univ. (Poland); M. D. Thoreson, Purdue Univ. (United States); P. Nyga, Purdue Univ. (United States) and Military Univ. of Technology (Poland); V. M. Shalaev, Purdue Univ. (United States); S. Maćkowski, Nicolaus Copernicus Univ. (Poland)

895700 Dependence of metal-enhanced fluorescence on surface roughness [8957-24] A. François, B. Sciacca, A. Zuber, E. Klantsataya, T. M. Monro, The Univ. of Adelaide (Australia)

8957 OP Metal-enhanced fluorescence: effect of surface coating [8957-25]

M. Lismont, Univ. de Liège (Belgium) and The Univ. of Adelaide (Australia); A. François, The Univ. of Adelaide (Australia); L. Dreesen, Univ. de Liège (Belgium); T. M. Monro, The Univ. of Adelaide (Australia) 
8957 OU Size and wavelength dependency of saturable scattering by a single gold nanosphere embedded in dielectric material [8957-30]

Y.-T. Huang, H.-Y. Wu, H. Lee, National Taiwan Univ. (Taiwan); R. Oketani, Y. Yonemaru, Osaka Univ. (Japan); T.-Y. Su, National Taiwan Univ. (Taiwan); M. Yamanaka, S. Kawata, S. Shoji, K. Fujita, Osaka Univ. (Japan); S.-W. Chu, National Taiwan Univ. (Taiwan)

8957 OV Three-dimensional light manipulation by gold nanobumps [8957-31]

C. M. Chang, National Taiwan Univ. (Taiwan) and Research Ctr. for Applied Sciences (Taiwan); M. L. Tseng, National Taiwan Univ. (Taiwan); B. H. Cheng, Research Ctr. for Applied Sciences (Taiwan) and National Cheng Kung Univ. (Taiwan); C. H. Chu, Y. Z. Ho, H. W. Huang, H.-K. Tsai, K. S. Chung, I.-D. Chiang, Y.-H. Cheng, National Taiwan Univ. (Taiwan); Y.-C. Lan, National Cheng Kung Univ. (Taiwan); D.-W. Huang, National Taiwan Univ. (Taiwan); A. Q. Liu, Nanyang Technological Univ. (Singapore); D. P. Tsai, National Taiwan Univ. (Taiwan) and Research Ctr. for Applied Sciences (Taiwan)

8957 OY Physical mechanism of Au nanopore formation on pyramid using electron beam irradiation [8957-34]

T. Yamaguchi, M. J. Park, Sun Moon Univ. (Korea, Republic of); N. K. Park, Seoul National Univ. (Korea, Republic of); S. S. Choi, Sun Moon Univ. (Korea, Republic of)

Author Index 
Proc. of SPIE Vol. $8957895701-6$

Downloaded From: https://www.spiedigitallibrary.org/conference-proceedings-of-spie on 26 Apr 2023 Terms of Use: https://www.spiedigitallibrary.org/terms-of-use 


\title{
Conference Committee
}

\author{
Symposium Chairs
}

James G. Fujimoto, Massachusetts Institute of Technology

(United States)

R. Rox Anderson, Wellman Center for Photomedicine, Massachusetts General Hospital (United States) and Harvard School of Medicine (United States)

Program Track Chairs

Paras N. Prasad, University at Buffalo (United States)

Dan V. Nicolau, McGill University (Canada)

\section{Conference Chairs}

Tuan Vo-Dinh, Fitzpatrick Institute for Photonics, Duke University (United States)

Joseph R. Lakowicz, University of Maryland School of Medicine (United States)

\section{Conference Program Committee}

A. Claude Boccara, Ecole Supérieure de Physique et de Chimie Industrielles (France)

Michael T. Canva, Laboratoire Charles Fabry, CNRS (France)

Volker Deckert, Institut für Photonische Technologien e.V. (Germany)

Bruce S. Dunn, University of California, Los Angeles (United States)

Christopher D. Geddes, University of Maryland, Baltimore (United States)

Zygmunt Karol Gryczynski, University of North Texas Health Science Center at Fort Worth (United States)

Naomi J. Halas, Rice University (United States)

Ho-Pui A. Ho, The Chinese University of Hong Kong (Hong Kong, China)

Jiri Homola, Institute of Photonics and Electronics of the ASCR, v.v.i. (Czech Republic)

Laura Maria Lechuga, Centre d'Investigacions en Nanociència i Nanotecnologia (Spain)

Boris Mizaikoff, Universität UIm (Germany)

Shuming Nie, Emory University (United States)

Krishanu Ray, University of Maryland School of Medicine (United States)

Wei-Chuan Shih, University of Houston (United States) 
Weihong Tan, University of Florida (United States)

Andrew Taton, University of Minnesota, Twin Cities (United States)

Richard P. Van Duyne, Northwestern University (United States)

Jeffrey I. Zink, University of California, Los Angeles (United States)

\section{Session Chairs}

1 Plasmonics and SERS I

Tuan Vo-Dinh, Fitzpatrick Institute for Photonics, Duke University (United States)

2 Plasmonics and SERS II

Tuan Vo-Dinh, Fitzpatrick Institute for Photonics, Duke University (United States)

3 Plasmonic Biosensing I

Ho-Pui A. Ho, The Chinese University of Hong Kong (Hong Kong, China)

4 Plasmonic Biosensing II

Hsiangkuo Yuan, Duke University (United States)

5 Plasmonics and Fluorescence

Hsiangkuo Yuan, Duke University (United States)

6 Plasmonics and Nanophotonics

Janna K. Register, Duke University (United States)

7 Plasmonic Nanostructures

Janna K. Register, Duke University (United States) 